\title{
Õpilaste kaasamine STEM-haridusse
}

\author{
Joseph Krajcik $^{\text {al }}$, İbrahim Delen ${ }^{\mathrm{b}}$ \\ ${ }^{a}$ Michigani Ülikool \\ ${ }^{b}$ Uşaki Ülikool
}

\begin{abstract}
Annotatsioon
Artiklis käsitletakse STEM-õpikeskkonna arendamise võimalusi ning STEMi rakendamist põhi- ja keskkooliastmes, keskendudes järgmisele küsimusele: kuidas aidata õpilastel omandada põhjalikke ja integreeritud STEM-valdkonna teadmisi, et neil oleks praktilised teadmised ja probleemilahendusoskused, mis aitaks neil maailmas hakkama saada ja seda paremaks muuta? Lisaks tutvustatakse STEMõppeks sobiva keskkonna hindamise kriteeriume ning käsitletakse probleeme, millega õpetajatel tuleb STEM-ainete õpetamisel kokku puutuda. Meie määratluse järgi on STEM loodusteaduste, tehnoloogia, inseneriteaduse ja matemaatika ühendamine eesmärgiga lahendada pakilisi isiklikke ja ühiskondlikke probleeme. Õpilaste kaasamine STEM-valdkonda tähendab nende kaasamist disainiprotsessi. STEM-maailmas on disain õpilaste mõttemaailma lahutamatu osa. Disainiprotsess on mittelineaarne ja oma olemuselt korduv, kuid nõuab disainiprobleemi kindlaksmääramist ja selget sõnastamist, probleemi kohta juba teada oleva teabe uurimist, võimalike lahenduste pakkumist, prototüüpide (tehisesemete) väljatöötamist, et lahendusi demonstreerida, ning tagasiside jagamist ja saamist. Disainile keskenduva STEM-hariduse kaudu on võimalik toetada õpilasi suurte loodus- ja inseneriteaduslike ideede ning oluliste praktiliste loodus- ja inseneriteaduslike teadmiste omandamisel. Samuti võimaldab STEM-haridus motiveerida õpilasi, et neil tekiks omanikutunne ning vajadus oma ideid tutvustada ja tulemuslikult tegutseda. Enamgi veel, STEM-õpikeskkonda kaasatud õpilased saavad arendada selliseid 21. sajandil vajalikke oskusi nagu probleemilahendus- ja suhtlemisoskus ning koostöövõime.
\end{abstract}

Võtmesõnad: STEM-haridus, disainipõhine haridus, õpikeskkond, integreeritud teadmised, praktilised loodus- ja inseneriteaduslikud oskused, suured loodus- ja inseneriteaduslikud ideed

1 College of Education, Michigan State University, 620 Farm Lane, East Lansing, MI 48824, USA; krajcik@msu.edu 


\section{Sissejuhatus}

Pole mingit kahtlust, et loodusteaduste, tehnoloogia, inseneriteaduse ja matemaatika (STEM) valdkonna teadmised on planeedi jätkusuutlikkuse tagamiseks möödapääsmatud. STEM-haridus on vajalik selleks, et tööjõud oleks valmis probleemideks ja võimalusteks, mis neid ees ootavad, ning tagada, et ka tulevikus saaksime elada jätkusuutlikus ja elujõulise majandusega maailmas. Tarkade otsuste tegemiseks on tarvis, et avalikkus oleks STEM-valdkonnas pädev. USA Riikliku Teadusfondi haridus- ja personaliosakonna teadus- ja õppeüksuse juhataja Evan Heit on öelnud, et „STEMhariduse tõhustamiseks on meil tarvis põhjalikumaid teadmisi sellest, kuidas inimesed õpivad alates lapsepõlvest kuni täiskasvanueani ..." (National Science Foundation, 2016). Pealegi on täisväärtuslikuks ja mõtestatud eluks 21. sajandil tarvis põhjalikke ja praktilisi teadmisi loodusteaduste ja inseneriteaduse valdkonna ideedest ja tavadest, samuti loovust, probleemilahendus- ja suhtlemisoskust ning otsustusvõimet, mille abil rakendada STEM-valdkonna ideid.

Meie igapäevaelu on STEM-valdkonnaga tihedalt läbi põimunud. Mobiilitehnoloogia on vaid üks näide selle kohta, kuidas STEM meie igapäevaelu mõjutab ja kuivõrd erinev oleks see ilma tehnoloogiata. Kuidas töötab traadita internet? Kuidas on võimalik, et meie mobiiltelefonid suudavad audio- ja videoinformatsiooni nii pikkade vahemaade taha edastada? Kuidas tagada nende seadmete töötamiseks vajalik energia? Muud üliolulised küsimused, millele STEMi abil vastust otsitakse, on järgmised: kuidas vähendada süsinikuheidet ja sellest hoolimata nautida paljusid 21. sajandi mugavusi, näiteks auto ja lennukiga reisimist? Uued läbimurded loodusteadustes, tehnoloogias, inseneriteaduses ja meditsiinis on samuti meie elu paremaks muutnud. 13. aprillil 2016 teatas New York Times (Carey, 2016), et üks neljajäsemehalvatust põdev noormees saavutas mõningase kontrolli oma parema käe ja sõrmede liikuvuse üle, kasutades tehnoloogiat, mis edastas tema mõtted käe- ja sõrmelihastele. See tehnoloogia, sealhulgas mehe varrukasse peidetud arvutiga ühendatud kiip, mis paigaldati mehe ajju, võimaldab tal pudelist vett valada ja kõrrega vedelikku segada. See läbimurre nõudis eri valdkondade spetsialistide, sealhulgas arvutiteadlaste, biotehnoloogiainseneride ja meditsiinispetsialistide ühiseid jõupingutusi. Need spetsialistid vajavad põhjalikke ja praktilisi teadmisi oma valdkonnast, kuid ühtlasi head kujutlusvõimet ja loovust, mille abil uusi ideid omavahel ühendada.

Olgugi et STEM-valdkonna uued arengusuunad - geneetika, nanoteadus, neuroteaduse tehnoloogiad ja inseneriteadus - pakuvad piiramatuid võimalusi inimeste heaolu parandamiseks, on need ja teised loodusteaduslikud, 
tehnoloogilised ja insenerialased läbimurded tekitanud hulgaliselt üleilmseid probleeme, näiteks veereostus, ülekaalulisusest tulenevad terviseprobleemid, kliimamuutused ning geneetiliselt muundatud toiduga seotud eetikaprobleemid. Pealegi ootab enamikku praegu lapseeas olevaid inimesi karjäär, mis nõuab põhjalikke ja praktilisi teadmisi STEM-valdkonnast, võimet teha koostööd teistega ja suutlikkust probleeme lahendada, otsuseid langetada ning olla uuenduslik. Igal lapsel on vaja omandada põhjalikud STEM-teadmised, hoolimata sellest, kas nad kavatsevad tegutseda STEMis või mõnes muus valdkonnas. Tänapäeva maailmas ei ole meil STEMist pääsu.

\section{Mis on STEM-haridus?}

Mis on STEM-haridus? Ükskõik kas kutsume seda STEMiks või STEAMiks (loodusteadused, tehnoloogia, inseneriteadus, kunst ja matemaatika), selge on see, et Ameerikast Koreani liigub loodusteaduslik haridus selle suunas. USA Riiklik Teadusnõukogu (National Research Council, 2014) on leidnud, et integreerituma STEM-hariduse nimel tuleb luua seoseid tegevuste ja materjalide vahel, samuti teadusharude vahel ning mõõta ja mõista, kuidas õpilased teadmisi omandavad. Ühes teises teadusnõukogu aruandes on õpilaste STEM-hariduse kriteeriumiteks nende kaasamine uurimustesse ja projektidesse, mis on seotud põhiõppeainete ning loodusteaduste, matemaatika ja inseneriteadusega (National Research Council, 2011a). STEM-hariduse vältimatuid komponente on liikumine automaatsete tegevuste juurest päris elus ette tulevate probleemide lahendamise juurde.

Ühes oma varasemas uurimuses pakkusime välja disainiprotsessi olulised etapid, võttes aluseks Fortuse, Dershimeri, Krajciki, Marxi ja MamlokNaamani mudeli (2004). Rõhutasime, et selle protsessi puhul on olulised järgmised etapid: disainiprobleemi määratlemine ja uurimine, lahenduste leidmine ja tehisesemete valmistamine (Krajcik \& Delen, 2017). Siinkohal tuleb märkida, et disainimine ei pea ilmtingimata tähendama mingi füüsilise konstruktsiooni loomist, kuna USA Riiklik Teadusnõukogu (National Research Council, 2014) on leidnud, et lõpptulemus peaks olema „inseneriteaduslik või tehnoloogiline disainikontekst" (lk 91).

STEMi võiks määratleda ka kui koondteadmisi, mis põhinevad loodusteadustel, tehnoloogial, inseneriteadusel ja matemaatikal, mis on küll eraldi seisvad, kuid siiski seotud teadusharud. Meie eelistame siiski STEMi terviklikumat määratlust, sest see peegeldab hästi, kuidas maailma teadlased ja insenerid tegelikult töötavad. Sisukam ja tulemuslikum oleks STEMist 
mõelda kui loodusteaduste (füüsika, keemia, bioloogia, geograafia ja kosmoseteaduse), inseneriteaduse, tehnoloogia ja matemaatika ühendajast, mille abil saab lahendada üksikisikute ja ühiskonna probleeme. Et tulla toime keeruliste ülesannetega, nagu kiibi paigaldamine inimajju, süsinikuheite vähendamine, vähem energiat tarbivate transpordivahendite (rongide, autode ja lennukite) ehitamine või päikeseenergia kasutamine, ei piisa ainult ühe valdkonna põhjalikest praktilistest teadmistest, kuigi need toetavad veelgi põhjalikumate ja kasutuskõlblikumate teadmiste omandamist, vaid vaja läheb ka teadmisi teistest valdkondadest. See võimaldab pakiliste ja keeruliste probleemide lahendamisel koostööd teha. Indiviididel on vaja ka loovust, et välja mõelda uusi võimalusi ja sünteesida ideid. Samas peavad nad oskama koostööd teha inimestega, kellel on teistsugused teadmised kui neil endil. Integreeritud teadmiste omandamine STEM-valdkonnas on üldhariduses möödapääsmatu, sest sellega luuakse alus, millele õppija saab toetuda, kui soovib oma teadmisi laiendada, probleeme lahendada ja uuendusmeelselt tegutseda.

Oma uurimuses eeldasime, et kui ehitada teadmiste omandamine eri valdkondade suurte ideede ümber, kui edastada teadmisi selliselt, et neid on võimalik kasutada uues kontekstis, kui õpilased rakendavad keeruliste probleemide lahendamiseks ja nähtustest arusaamiseks kriitilist meelt, probleemilahendusoskust, koostöövõimet ja suhtlemisoskust ning kui õpilased õpivad ennast analüüsima ja mõistavad, kuidas õppida, siis on neil aluspind, millele globaalse ühiskonna aktiivse liikmena rajada terve elu kestev õpe. Meie teine peamine eeldus on, et kõikidel õpilastel peaks olema võimalus saada kvaliteetset õpetust STEM-ainetes ja STEM-valdkonnas laiemalt. Meie eesmärk on toetada ja arendada õpilasi STEM-valdkonnas.

STEMi määratlemine teadusharusid ühendava sillana ei ole uus idee. Kui uurida Ameerika Teaduse Edendamise Assotsiatsiooni (AAAS) varasemaid aruandeid, näeme, et loodusteadust on määratletud kui nurgakivi või teadusharu, mis ühendab teisi teadusharusid (American Association, 1989). Arutledes peamiselt matemaatika, tehnoloogia ja loodusteaduste seoste üle, esitletakse AAASi aruandes (1989) matemaatikat kui teaduskeelt ja rõhutatakse, et teadusharud saavad üksteist toetada. See idee viis hiljem loodusteaduste, matemaatika, tehnoloogia ja inseneriteaduse (STEM) ühendamiseni eesmärgiga ette valmistada vajalike oskustega tööjõudu. Alguses rakendati STEM-haridust bakalaureuseprogrammides (Sanders, 2009). Kui mõisteti, et õpilased kaotavad huvi loodusteaduste vastu juba nooremates klassides (Osborne \& Dillon, 2008; National Research Council, 2012; Vedder-Weiss \& Fortus, 2012), asuti loodusteaduste populariseerimiseks STEM-õppeainetele enam rõhku panema ka põhi- ja keskkooliastmetes, 
kuigi USA Haridusministeeriumi inimõiguste ameti (U.S. Department, 2014) hinnangul õpetatakse vaid 50\% gümnaasiumitest arvutamist, samas füüsikat õpetatakse $63 \%$ koolidest. Lisaks rõhutatakse aruandes, et juurdepääs põhikursustele (nt bioloogia-, keemia-, algebrakursusele) on piiratud.

Siinses artiklis ei ole meie eesmärk arutleda STEM-õppeainete vähesuse üle. Selle asemel keskendume mitmesugustele STEM-haridusega seotud ideedele, näiteks sellele, kuidas parandada STEM-hariduse õpikeskkonda ja kuidas STEM-haridust anda. Kõigepealt võtame vaatluse alla küsimuse „Kuidas aidata õpilastel omandada põhjalikud ja integreeritud STEM-valdkonna teadmised, et neil oleks praktilised teadmised ja probleemilahendusoskused, mis aitaks neil maailmas hakkama saada ja seda paremaks muuta?". Artikli keskmes on õpikeskkonna kujundamine ja õppekavade arendamine eesmärgiga tagada integreeritud süvateadmiste omandamine STEM-valdkonnas kogu põhi- ja keskkooliastme vältel.

\section{Disain kui STEM-hariduse keskne idee}

Õpilaste kaasamine STEM-valdkonda tähendab nende kaasamist disainiprotsessi. STEM-maailmas on disain õpilaste mõttemaailmast lahutamatu. Seetõttu me muutsime Fortuse ja tema kolleegide (2004) disainiprotsessi mudelit nii, et seda saaks kasutada koolis. Nimelt on disain unikaalne mõtlemisviis ja õpilastele tänapäeva maailmas äärmiselt vajalik. Disain innustab õpilasi probleemidele lahendusi otsima.

Joonisel 1 on kujutatud üht võimalikku disainiprotsessi, mida saab koolis kasutada. Sellise disainiprotsessi puhul on ülioluline, et õpilased sõnastaksid ja määratleksid selgelt disainiprobleemi, uuriksid välja, mida selle probleemi kohta teatakse, pakuksid välja võimalikke lahendusi, looksid prototüüpe (tehisesemed), mille abil demonstreerida oma lahendusi, saaksid oma lahenduste kohta tagasisidet klassikaaslastelt ja teistelt asjatundjatelt ning annaksid ka ise teistele tagasisidet (üksikasjalikumat ülevaadet kõikidest kirjeldatud astmetest vt Fortus et al., 2004).

Disainiprotsess on mittelineaarne ja oma olemuselt korduv. Kuigi disainiprotsess algab sageli probleemi kindlaksmääramisega, võib see liikuda eri suundades. Kui õpilased on probleemi tuvastanud, võiksid nad saada tagasisidet probleemipüstituse kohta või uurida, mida on kõnealuse probleemi kohta teada. Kogutud infot võiksid nad kasutada oma disainiprobleemi täpsemaks sõnastamiseks. Selline disainiprobleemi üksikasjalik kindlaksmääramine on sobivate lahenduste leidmiseks ülimalt vajalik. Kui disainiprobleem on täpselt kindlaks määratud, hakkavad disainirühmad välja töötama võimalikke lahendusi. Selle tulemusena luuakse arvutis 
mudelid või prototüübid, millega katsetatakse, kas pakutud lahendused vastavad probleemi lahendamise kriteeriumitele. Prototüübi ehitamise ja katsetamise tulemusena kaasatakse õpilased andmete analüüsimisse, mille kaudu uuritakse välja, kas prototüüp vastab projekti kriteeriumitele. Prototüübi katsetamise põhjal tehtud järeldused võivad nõuda õpilastelt projekti põhjalikumat uurimist, mis omakorda võib viia veelgi selgema probleemipüstituseni.

Disainiprotsess on oma olemuselt ülimalt korduv. Enamik õpilasi ei ole harjunud korduvas protsessis osalema ja peavad seda nurjumiseks. Kuid kõik head tooted ja lahendused leitakse just korduva disainimise teel. Protsessi korduvus sõltub sellest, kas õpilased saavad katsetamise ja analüüsi kohta tagasisidet, kuid ka sellest, millised on kaaslaste ja asjatundjate esitatud kommentaarid. Tagasisidet võib sageli olla raske taluda, kuid just see parandab lõpptulemust.

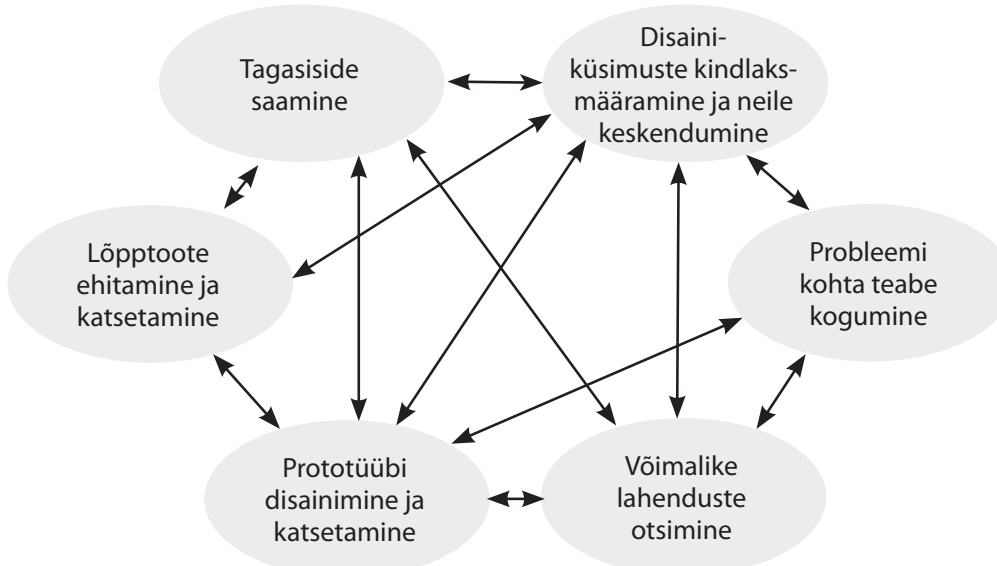

Joonis 1. Fortuse jt (2004) järgi kohandatud disainil põhinev loodusteaduste õppimise tsükkel

\section{Õppimise kohta käivate teadmiste kasutamine STEM-õpikeskkonna loomisel}

Uuringud loodusteaduste õppimise, kognitiiv- ja haridusteaduste valdkonnas on võimaldanud sõnastada peamised põhimõtted, millest tuleks STEM-õpikeskkonna loomisel lähtuda (Krajcik \& Shin, 2014; National Research Council, 2007, 2012; Sawyer, 2014). Need põhimõtted on järgmised: 1) toetada olulisimate teaduslike põhimõtete sügavat omandamist; 2) innustada õpilasi viisil, mis tekitaks tahtmise nähtusi mõista ja probleemidele 
lahendusi leida, kasutades selleks loodus- ja inseneriteaduslikke praktikaid, 3) luua õpilasi motiveeriv ja huvi pakkuv õpikeskkond, 4) luua ajapikku asjadest ja nähtustest terviklik arusaamine, 5) ühendada teaduslike ideede ning loodus- ja inseneriteaduslike praktikate kasutamine, et saavutada nähtuste terviklik mõistmine, ning 6) visualiseerida õpilaste mõttetegevust.

Millist mõju avaldavad need suured ideed STEM-valdkonna õpikeskkonnale ja õppekavadele? Õpilased peavad probleemide lahendamiseks kogu põhi- ja keskkooli vältel kasutama loodus- ja inseneriteaduslikku, matemaatilist ja tehnoloogilist mõtteviisi ning praktikaid, et neil tekiksid integreeritud ja praktilised teadmised STEM-valdkonnast. Allpool käsitleme lähemalt kõiki selliseid ideid ja nende mõju STEM-valdkonna õpikeskkonna loomisele.

\section{Suurte ideede süvaõpe}

Esiteks näitavad uuringud selgelt, et eksperdid struktureerivad oma teadmisi, mis toetuvad suurtele ideedele. Kuna ekspertidel on palju ideid, siis oleneb just struktureerimisest see, kuidas nad saavad oma teadmisi kasutades probleemidele lahendusi otsida. Mitte see, kui palju nad teavad, vaid see, kuidas on nende teadmised struktureeritud, annab ekspertidele võime probleeme lahendada. Seega tuleks keskenduda hästi struktureeritud taustsüsteemi loomisele. Kõige olulisemad on ideed ja nende seosed. Meie ülesanne on aidata õppijatel luua järk-järgult selliseid integreeritud taustsüsteeme, mis aitaksid neil probleeme lahendada, otsuseid langetada ja vajaduse korral rohkem teadmisi omandada.

Loodusainete õpetamise raamistik Ameerika põhi- ja keskkooliastmes (National Research Council, 2012) keskendub piiratud arvule loodus- ja inseneriteaduste kesksetele ideedele, mille tulemusena kujunevad ajapikku välja hästi struktureeritud teadmised. Need kõikide teadusharude põhiideed ehk suured ideed on vajalikud selleks, et selgitada ja ennustada mitmesuguseid nähtusi ning lahendada probleeme. Teadusharude põhiideedel on suur mõjuvõim, sest need on iga teadusharu keskmes: neile tugineb mõtlemine, kui proovitakse mõista mis tahes nähtusi, ning neile rajatakse uute teadmiste omandamine teadusharu sees ja nende abil luuakse seoseid teiste ideedega (National Research Council, 2012; Stevens, Sutherland, \& Krajcik, 2009). Selline põhiideedele keskendumine aitab hoiduda õpikutele omasest paljude teemade pinnapealsest käsitlemisest (Kesidou \& Roseman, 2002) ja annab õpilastele võimaluse jõuda nähtuste tervikliku mõistmiseni probleemide lahendamise ja otsuste tegemise eesmärgil. Näiteks peavad insenerid oma töös probleemide lahendamiseks kasutama mitmete teadusharude 
ideid. Et aidata õpilastel seletada nähtusi ja leida lahendusi probleemidele, tuleks meie arvates põhi- ja keskkooliastmes keskenduda iga valdkonna suurtele ideedele (teadusharude põhiideedele), mitte seosetutele faktidele.

STEM-valdkonnaga seotud kogemuste puhul, milles on tähtis koht ka disainil, rõhutatakse vajadust ühendada eri teadusharudest pärit ideid. Honey, Pearson ja Schweingruber (National Research Council, 2014) on väitnud, et kui õppijad on kaasatud STEM-tegevustesse, siis „vajavad nad abi asjakohaste loodus- ja täppisteaduslike ideede toomiseks inseneriala ja tehnoloogia disainikeskkondadesse, et ühendada ideid tulemuslikult ja korraldada need ümber viisil, mis peegeldab normatiivseid teaduslikke ideid ja tavasid“ (lk 5).

Inseneriteaduse kontseptsioonide tunnustamine olulise loodusteadusliku õppe-eesmärgina on Ameerika Ühendriikides uudne. Põhi- ja keskkooliastme loodusteaduste õppekavade raames tunnustatakse inseneriteaduse, tehnoloogiaõpetuse ja rakendusteaduste põhiideid samaväärselt füüsika, bioloogia, geograafia ja kosmoseteaduse põhiideedega. Selles raamistikus selgitatakse kahte suurt inseneriteaduse põhiideed. Esimene neist keskendub projekteerimisele, mille käigus kasutavad insenerid probleemide lahendamiseks mitmesuguseid võtteid, näiteks probleemi kindlaksmääramine, maketi loomine ja kasutamine, taustauuringud, analüüs ja andmete tõlgendamine, matemaatilise ja arvutusliku mõtlemise rakendamine, lahenduse leidmine. Inseneritöö nõuab väga paljude teadmiste ja oskuste ühendamist, näiteks on tarvis erialaseid teadmisi mitmesuguste kriteeriumite ja piirangute kohta, sealhulgas ohutus, töökindlus ja välimus. Probleemide lahendamisel tuleb arvestada sotsiaalsete, kultuuriliste ja keskkonnamõjudega. Samuti tuleb osata luua projekteerimiseks vajalikke füüsilisi makette ja arvutimudeleid, analüüsida andmeid, mida saadakse prototüüpidelt, ning optimeerida lahendust, võttes arvesse arutelusid ja kompromisse. Teine teadusharu põhiidee keskendub inseneriteaduse, tehnoloogia, loodusteaduste ning ühiskonna vahelistele seostele. Sageli tekitavad uued teaduslikud avastused vajaduse uute tehnoloogiate ja nende rakendamise järele. Samal ajal annavad uued tehnoloogiad võimaluse uute teadusuuringute tegemiseks. Nagu eespool mainitud, on loodus- ja inseneriteaduslikel ning tehnoloogilistel edusammudel ka ülisuur mõju inimühiskonnale sellistes valdkondades nagu tervishoid, kliima ja looduskeskkond.

Tabelis 1 esitatakse kokkuvõte teadusharude põhiideedest põhi- ja keskkooliastme loodusteaduste õppekavades. Teadusharude põhiideedest tuleks mõelda kui suurtest ideedest, mis käivitavad praktilise mõtlemise (Duncan, Krajcik, \& Rivet, 2016). 
Tabel 1. Teadusharude põhiideed põhi- ja keskkooliastme loodusteaduste õppekavas (Duncan et al., 2016; National Research Council, 2012)

\begin{tabular}{|c|c|}
\hline Bioteadused & Füüsika \\
\hline $\begin{array}{l}\text { LS1: molekulidest organismideni: } \\
\text { struktuurid ja protsessid } \\
\text { LS2: ökosüsteemid: vastastikmõjud, energia } \\
\text { ja dünaamilisus } \\
\text { LS3: pärilikkus: pärilikkus ja tunnuste } \\
\text { varieeruvus } \\
\text { LS4: bioloogiline areng: ühtsus ja } \\
\text { mitmekesisus }\end{array}$ & $\begin{array}{l}\text { PS1: ained ja nende vastastikmõjud } \\
\text { PS2: liikumine ja tasakaal: jõud ja } \\
\text { vastastikmõjud } \\
\text { PS3: energia } \\
\text { PS4: lained ja nende kasutamine } \\
\text { infoedastustehnoloogiates }\end{array}$ \\
\hline Geograafia ja kosmoseteadus & Inseneriteadus ja tehnoloogia \\
\hline $\begin{array}{l}\text { ESS1: Maa asukoht universumis } \\
\text { ESS2: Maa ökosüsteemid } \\
\text { ESS3: Maa ja inimtegevus }\end{array}$ & $\begin{array}{l}\text { ETS1: projekteerimine } \\
\text { ETS2: seosed inseneriteaduse, tehnoloogia, } \\
\text { loodusteaduste ja ühiskonna vahel }\end{array}$ \\
\hline
\end{tabular}

Märkus. LS - bioteadused, PS - füüsika, ESS - geograafia ja kosmoseteadus, ETS - inseneriteadus ja tehnoloogia

See raamistik sisaldab ka teisi suuri ideid, mis ei kuulu üksnes ühe teadusharu alla, vaid on olulised kõikide teadusharude jaoks. Selliseid suuri ideid nimetatakse teadusharudeülesteks kontseptsioonideks. Need kontseptsioonid koosnevad suurtest teaduslikest ideedest, mida kasutatakse kõikides teadusharudes, kuid mis on igale teadusharule hädavajalikud, sest neid on tarvis nähtuste mõistmiseks või probleemide lahendamiseks. Teadusharudeüleseid kontseptsioone sobivad hästi näitlikustama põhjus ja tagajärg, süsteemid, struktuurid, suurus, proportsionaalsus ja mõõtmed ning aine ja energia.

Tabelis 2 on esitatud teadusharudeüleste kontseptsioonide loend. Teadusharudeülesed kontseptsioonid on probleemide lahendamisel hädavajalikud, sest võimaldavad näiteks välja selgitada, milline on energia liikumine (voog) süsteemi sees. Samamoodi nagu teadusharude põhiideed, toetavad ka teadusharudeülesed kontseptsioonid probleemide lahendamise ja otsuste tegemise protsessi. Et muuta teadusharudeülesed kontseptsioonid kasutuskõlblikeks teadmisteks, tuleb need õppekava kaudu õpilastele selgeks teha. Sageli eeldatakse, et õpilased saavad neist kontseptsioonidest aru, kuid tegelikult on õpilastel neid raske mõista ja kasutada. Näiteks on skaala, põhjus ja tagajärg ning struktuur ja funktsioon nanoteaduse jaoks üliolulised ideed. Õppekava peab toetama õpilasi selliste oluliste, sageli tagaplaanile jäänud ideede omandamisel. 
Tabel 2. Teadusharudeülesed kontseptsioonid põhi- ja keskkooliastme õppekavade raamistikus (National Research Council, 2012)

1. Mustrid. Mustrid, mille kordumist on tähele pandud looduses või inimeste loodud maailmas, võivad disaini ja inseneriteaduse valdkonnas anda vastuseid küsimustele suhete ja tegurite kohta, mis võivad tekkinud probleemi mõjutada, või selle kohta, kuidas disaini paremaks muuta.

2. Põhjus ja tagajärg. Igal sündmusel on põhjus, mis viib teatud tulemuseni. Loodus- ja inseneriteadustes uuritakse väga sageli, miks üks või teine asi juhtus. Toote täiustamiseks peavad insenerid teadma, miks seade rikki läks. Insenerid ja teadlased pingutavad selle nimel, et leida sündmuste põhjuseid.

3. Mõõtmed, proportsioon ja kogus. Kui vaadelda loodusnähtusi või inimese loodud nähtusi, on oluline teada, mis on erinevate mõõtmete, aja, koguse ja energia puhul oluline ning kuidas need erinevused võivad mõjutada süsteemi toimimist. Süsteemi suuruse muutumine võib mõjutada süsteemi struktuuri.

4. Süsteemid ja süsteemimudelid. Teadlased ja insenerid määravad väga hoolikalt kindlaks süsteemi, mida nad uurivad. Nad selgitavad täpselt välja süsteemi piirid ja valmistavad täpse mudeli. Mudelite ehitamise käigus kontrollivad ja katsetavad teadlased ning insenerid ideid, mis mõjutavad nähtusi looduses või tooteid disainimaailmas (Damelin, Krajcik, McIntyre, \& Bielik, 2017).

5. Energia ja mateeria: vool, tsüklid ja talletamine. Energia ja mateeria käitumine mõjutab kõiki aineid. Energiavoo ja mateeria jälgimine süsteemis aitab teadlastel ning inseneridel mõista süsteemisiseseid võimalusi ja piiranguid.

6. Struktuur ja funktsioon. Objekti, süsteemi või elusolendi struktuurist sõltuvad selle omadused ja toimimine. Näiteks mõjutab molekulide struktuur nende omadusi. Seda teades saavad nanoteadlased manipuleerida aatomeid nii, et tekiksid uued, teistsuguste omadustega molekulid (Stevens et al., 2009).

7. Stabiilsus ja muutumine. Kõik looduslikud ja inimese loodud süsteemid muutuvad aja jooksul. Oluline on teada, mis tingimustel jääb süsteem tasakaalu. Teadlased ja insenerid pingutavad selle nimel, et mõista süsteemide muutumise ja teisenemise põhjuseid.

Tähelepanu tuleks pöörata sellele, kuidas erinevad teadusharudeülesed kontseptsioonid omavahel kattuvad. Kui uuritakse, kuidas sõltuvad molekulide struktuurist aine makroomadused, kasutatakse vähemalt nelja teadusharudeülest kontseptsiooni: mustrid (aine omadused), põhjus ja tagajärg (struktuurist sõltuvad omadused), mõõtkava (molekulid molekulaartasandil ja omadused makrotasandil) ning struktuur ja funktsioon (molekulide struktuur mõjutab molekulide omadusi).

Kõik STEMil põhinevad disainiprojektid peavad keskenduma sellele, et õpilased omandaksid põhjalikud teadmised suurtest ideedest, mida on võimalik ära kasutada, kui otsitakse lahendusi muudele probleemidele või püütakse nähtustest aru saada. STEM-valdkonna õpikeskkonna loomisel tuleb põhiideede ja teadusharudeüleste kontseptsioonide edastamise nimel järjepidevalt pingutada. 


\section{Tutvumine teadus- ja insenerivaldkonna praktikatega}

Põhi- ja keskkooli loodusteadusliku hariduse õppekavas rõhutatakse, et loodus- ja inseneriteaduse õppimiseks on vaja loodus- ja inseneriteaduse rakendamist praktikas, et kaasata õpilasi loodus- ja inseneriteadusliku disaini loomisse (STEM). Loodus- ja inseneriteaduse rakendusalad hõlmavad mitmeid viise, mille abil teadlased uurivad ja mõistavad maailma ning insenerid täiustavad tehismaailma ja lahendavad probleeme. Tabelis 3 on kokkuvõtlikult tutvustatud kaheksat teaduslikku praktikat. Inseneriteaduses levinud praktika lisamine nende hulka näitab, kuivõrd olulised on need õpilastele, kes ópivad probleemidele lahendusi leidma. Seda on kasulik kasutada ka õppeprotsessi toetamiseks. Sellised praktikad eeldavad aktiivset tegutsemist ja hõlmavad tegevusi, millega hakkama saamist õpilastelt oodatakse.

Kuigi eespool loetletud praktikad on esitatud kindlas järjekorras, ei tähenda see, et nende kasutamisel tuleks seda järgida. Pigem võiks praktikaid käsitleda kui rekursiivset protsessi. Ühtlasi on oluline mõista, et nimetatud praktikad toimivad koos ehk üldjuhul tuleb probleemide lahendamiseks ehitada nii mudel kui ka analüüsida andmeid.

Tabel 3. Loodus- ja insenerivaldkonna praktikad (National Research Council, 2012; Schwarz, Passmore, \& Reiser, 2016)

1. Küsimuste esitamine (loodusteaduse jaoks) ja probleemide kindlaksmääramine (inseneriteaduse jaoks). Teaduslike uuringute tegemiseks peavad õpilased esitama küsimusi ja neid täpsustama. Et luua inseneriteaduslikke mudeleid, peavad õpilased oskama kindlaks määrata ja täpsustada probleeme.

2. Mudelite väljatöötamine ja kasutamine (loodus- ja inseneriteadus). Samamoodi nagu teadlased ja insenerid, peavad õpilased valmistama ja kasutama mudeleid, mille abil saab uurida ja avastada loodust ning tehismaailma. Teadlased ehitavad mudeleid, et selgitada nähtusi, ja genereerivad andmeid, et nende põhjal ennustada tulevikus juhtuda võivaid sündmusi. Insenerid ehitavad mudeleid, et määrata kindlaks, mis tingimustel võivad toodetel vead tekkida, või et testida võimalikke probleemilahendusi. Peaksime õpetama õpilasi looma, hindama ja viimistlema mudeleid korduvate tsüklite kaudu, mille käigus võrreldakse oma oletusi tegelikkusega ja tehakse muudatusi, omandades arusaama nähtustest või kohandades enda loodud prototüüpi. Mudelid põhinevad tõenditel, ja kui ilmnevad uued tõendid, mida ei suudeta mudeliga seletada, peaksid õpilased mudelit muutma. See on teaduse peamine eeldus.

3. Uuringute planeerimine ja elluviimine (loodus- ja inseneriteadus). Looduse uurimisel peavad õpilased teadlaste kombel uuringuid planeerima ja need elu viima, et leida vastused neid huvitavatele küsimustele. Tehiskeskkonna uurimisel peavad õpilased inseneride kombel planeerima ja tegema uuringuid, mis aitavad neil probleemi paremini mõista. 
4. Andmete analüüsimine ja tõlgendamine (loodus- ja inseneriteadus). Kui looduse või tehismaailma kohta on andmed kogutud, peavad õpilased nagu teadlased ja insenerid neid analüüsima ja tõlgendama, et leida mustreid, mis võimaldavad uuritavat süsteemi paremini mõista. Nii teadlased kui ka insenerid teevad otsuseid, analüüsides ja tõlgendades andmeid. Andmed ei muutu tõendusmaterjaliks enne, kui neid kasutatakse mõne väite tõestamiseks.

5. Matemaatika ja arvutusliku mõtlemise kasutamine (loodus- ja inseneriteadus). Loodus- ja inseneriteaduse oluline osa on muutujatevaheliste suhete kindlaksmääramine, mis aitab uuritavat süsteemi paremini mõista. Suhted võimaldavad tulemusi terviklikumalt ja täpsemalt ennustada ning seletada. Arvuti abil saavad õpilased andmeid koguda, analüüsida ja graafiliselt esitada. Arvutitega saab teha arvutusi ja graafikuid, võimaldades õpilastel keskenduda mustritele ja suhetele. Arvuti abil on võimalik ka muutujatega manipuleerida, et näha, kuidas ühed muutujad mõjutavad teiste muutujate käitumist.

6. Seletuste pakkumine (loodusteadus) ja lahenduste leidmine (inseneriteadus). Teaduse põhiolemuseks on seletuste leidmine selle kohta, kuidas loodus toimib, samas kui inseneride peamine eesmärk on luua lahendusi, mis toimiksid tehismaailmas. Õpilased tuleb kaasata seletuste ja lahenduste leidmisse.

7. Tõendusmaterjali kasutamine argumenteerimisel (loodus- ja inseneriteadus). Kogu teadus sõltub argumentide kasutamisest. Seletuste leidmisel ja disainilahenduste väljatöötamisel peavad õpilased tõenditele toetudes oma seisukohti kaitsma, ja kui esitatakse tõendeid, mis on vastuolus nende seletuste ja lahendustega, peavad nad oma seisukohad üle vaatama.

8. Teabe kogumine, hindamine ja edastamine (loodus- ja inseneriteadus). Asjakohase teadusliku ja tehnilise teabe lugemine, tõlgendamine ja hindamine on oluline teaduslik praktika. Peaksime eeldama, et õpilased teevad sama, kui püüavad mõista mõnd nähtust ja leida lahendust mõnele probleemile. Nii nagu teadlased ja insenerid, peaksid ka õpilased suutma oma järeldusi edastada nii kirjalikus kui ka suulises vormis.

\section{Õpilasi motiveeriva ja neile huvi pakkuva keskkonna loomine}

Õppetöö seostamine õpilaste igapäevakogemustega on STEM-õpikeskkonna loomise ülioluline osa. Motiveeriva ja kaasahaarava konteksti pakkumine õpilastele on õpikeskkonna loomise võtmeküsimus. Probleemi asetamisel konteksti seostatakse õppetegevus tähtsa elulise olukorraga, mistõttu on ka õppimine tulemuslikum. Konteksti asetatud probleem või võtmeküsimus aitab õpilastel mõista, kuivõrd asjakohane ja oluline on õppimine. Samas ei pruugi õpilased kohe aru saada, kuidas mõni küsimus on reaalse maailmaga seotud, ega tajuda selle tagajärgi. Hea probleemipüstitus või aktuaalse küsimuse leidmine tekitab õpilastes huvi ja aitab luua seoseid nende igapäevaeluga. Aktuaalsete küsimuste abil saab õpitava asetada igapäevaelu konteksti, kaasata erineva taustaga õpilasi ja ühendada kogu mooduli õppe-eesmärgid. Õppima innustava keskkonna loomiseks on 
ilmtingimata tarvis tekitada õpilastes teadasaamisvajadus. Sageli alustame oma tööd sellest, et laseme õpilastel mõnd põnevat ja põhjapanevat nähtust kogeda (Krajcik \& Czerniak, 2013). Näiteks võib kaasata õpilased generaatoriga ühendatud tuule- või veeturbiini ehitamisse, et selle abil elektripirn põlema saada. Sellist tegevust võiks alustada küsimuse või järgmise probleemiasetusega: kuidas süüdata vee- või tuuleenergia abil elektripirn?

Õpikeskkond tuleks rajada huvipakkuvatele probleemidele ja küsimustele (Delen \& Krajcik, 2016; Krajcik \& Czerniak, 2013), mis motiveerivad õpilasi rakendama loodus- ja inseneriteaduslikke ideid, mille õppimine on neil parasjagu käsil. Tegevus klassiruumis peaks keskenduma nähtuste ja õpilaste kogemustel põhinevate disainiprobleemide esitlemisele, uurimistöö tegemisele, tehnoloogiliste abivahendite kasutamisele ja teadmisi süvendavate materjalide lugemisele, mis avardaks õpilaste isiklikke kogemusi seoses nähtustega ja toetaks nende loodusteaduslikku kirjaoskust.

Klager ja tema kolleegid (2017) näitasid, et projektipõhisel sekkumisel õpiprotsessi keskkooli keemia- ja füüsikatunnis oli võrreldes tavapärase õpetamisviisiga oluliselt positiivsem mõju kolmest kahele loovuse näitajale. Paranesid nii kujutlusvõime kui ka eri seisukohtade käsitlemise oskus. See on ka arusaadav, võttes arvesse, millist rõhku pannakse projektipõhises õppes argumenteerimisele, graafilisele kujutamisele, vaidlustamisele, uute ideede läbiproovimisele ja motiveeriva konteksti pakkumisele. Õpilasi aktiveeriva küsimuse kasutamine projektipõhises õpikeskkonnas sundis õpilasi kasutama kujutlusvõimet ja leidma probleemidele erisuguseid lahendusi, selle asemel et lasta endale n-ö õige vastus ette öelda. Kuna disainipõhistel keskkondadel on palju sarnast projektipõhiste keskkondadega, siis võib neil olla ka sama mõju. Üldiselt peaksid projekti- ja disainipõhised õpikeskkonnad põhi- ja keskkooliõpilaste puhul soodustama loovat mõtlemist ja kujundama probleemilahendusoskust.

\section{Teadmiste omandamine pikema ajavahemiku jooksul}

Uuringud on näidanud, et õppimine on pideva arengu protsess. Õpilastel võtab keeruliste ideede omandamine aega, sest nad peavad nende mõistmisega vaeva nägema (National Research Council, 2007; Sawyer, 2014) ning kasutama neid nähtuste seletamiseks ja probleemide lahendamiseks. Arengu käigus täiendavad ja seovad õpilased varasemaid teadmisi teadlikult uutega, et luua ajapikku mitmekesine seostatud teadmiste pagas (National Research Council, 2007). Nii arendatakse õpilaste teadmisi viisil, mis võimaldab neil mõista keerulisi teaduslikke ideid omavahel lõimitult (Corcoran, Mosher, \& Rogat, 2009; National Research Council, 2007). Samas ei ole teadmiste kasv arenguga kaasnev paratamatus, vaid see sõltub 
siiski õpetamisviisist ja peamistest õppimiskogemustest (sealhulgas hindamised) nii formaalses kui ka mitteformaalses keskkonnas, mis toetavad õpilasi, kui nad järk-järgult jõuavad üha keerulisemate ideede mõistmiseni ja nende omavahelise seostamiseni (Corcoran et al., 2009). Kui me oleme midagi viimastel aastatel õppinud, siis on see mõistmine, kuivõrd oluline on ideede selge püstitamine ja hindamine, mis aitavad õppijatel luua olukorrast terviklikku arusaama (Roseman, Stern, \& Koppal, 2010). Selline arenguperspektiiv on vajalik, et aidata kõikidel õpilastel jõuda STEM-valdkonna süvateadmisteni, mis on 21. sajandil hädavajalikud. Arenguperspektiiv on eriti asjakohane STEM-valdkonna õpikogemuse omandamisel, sest STEMvaldkonnaga seotud kogemused muutuvad üha keerulisemaks. Seega peavad STEM-õppekava materjalide koostajad köitma õpilasi viisil, mis paneks nad seostama uusi ideid juba varem õpituga. Niimoodi õpivad õpilased ajapikku lahendama järjest keerulisemaid probleeme.

\section{Praktikate ja suurte ideede ühendamine, et lahendada probleeme ja mõista nähtusi}

Situatsioonõpe lähtub eeldusest (Greeno \& Engestrom, 2014; National Research Council, 2007), et õpilased saavad ainest paremini aru siis, kui nende teadmised tekivad ideede rakendamisest elulises olukorras. Et omandada kasutuskõlblikke teadmisi, tuleb õpilasel selgeks saada teadusharule omased ideed koos praktikaga ja omandada praktilised oskused, tegutsedes teadusharu sisust lähtudes. Meie jaoks tähendavad kasutuskõlblikud teadmised, et omandatud on terviklik teadmiste struktuur, mille abil on võimalik probleeme lahendada, nähtusi mõista ja vajaduse korral teadmisi juurde hankida. Kasutuskõlblike teadmiste omandamisel ei tohi teadmisi ja tegevusi lahus hoida, vaid neid tuleb õppida lõimitult. See eeldus toetab loodus- ja inseneriteaduslike praktikate, teadusharu põhiideede ja teadusharudeüleste kontseptsioonide ühiskasutamist, mis aitab loodusnähtusi mõista ja probleeme lahendada (National Research Council, 2012). Kuna teadus koosneb nii teadmiste kogust kui ka protsessist, mille käigus seda teadmiste kogu arendatakse, siis on teaduse õppimisega samad lood: teaduslikku ideed ei ole võimalik omandada ilma seda teaduslikus praktikas kasutamata ja vastupidi - praktikat ei saa omandada teaduslikust ideest eraldi. Kui me tahame, et õpilased oleksid võimelised teaduslikku ideed rakendama, siis peavad nad olema sellest ideest innustunud ja kasutama asjakohast teaduslikku praktikat, ning kui me tahame, et õpilased mõistaksid teaduslikku praktikat, siis peame kasutama sellist praktikat, mis oleks seotud teadusliku ideega. Praktikate, põhiideede ja teadusharudeüleste kontseptsioonide ühendamist nimetatakse kolmedimensiooniliseks õppimiseks. 
Õpilaste toetamine loodus- ja inseneriteaduse õppimisel tähendab teaduslike ideede (teadusharude põhiideede ja teadusharudeüleste kontseptsioonide) ühendamist loodus- ja inseneriteaduslike praktikatega, millele saab rajada põhjalikud kasutuskõlblikud teadmised. Neid teadmisi on tarvis selleks, et mõista füüsilist maailma, milles me elame, ning valmistada õpilased ette STEM-valdkonna karjääriks. Teaduskirjandus pakub tõendeid selle kohta, et teadusliku idee mõistmine on mingil seletamatul põhjusel seotud kontekstiga, milles õpilane selle mõistmiseni jõuab (National Research Council, 2007). STEM-ainete õppimiseks peavad õpilased olema kaasatud STEM-valdkonna tegevustesse.

\section{Õpilaste mõttetegevuse visualiseerimine}

Oma töös kaasame õpilasi tehisesemete valmistamisse, mille tulemuseks on selliste disainilahenduste esitamine, mis vastavad projekti nõuetele ja töörühmas kokkulepitule. Tehisesemete ehitamiseks peavad õpilased töörühmades koostööd tegema. See hõlmab ka ülesande täitmiseks vajalike seadmete ehitamist (nt elektripirni põlema panemine või kella helistamine mitme energiaülekande abil). Tehisesemete ehitamine võib viia põhjalike teadmisteni. Sama oluline on asjaolu, et see võib tekitada õpilastes isikliku omandi tunde, sest nad ise on saanud midagi kujundada (Fortus et al., 2004). Keskendumine probleemide lahendamisele nõuab kogu STEMmoodulite vältel õpilastelt oma tehisesemete (disainilahenduste) loomist, muutmist ja parandamist ning põhjalike ja keeruliste teaduslike teadmiste omandamist. Õpilaste kaasamine selliste mudelite ehitamisse, mis esindaksid nende disainilahendusi, ei aita kaasa mitte üksnes süvateadmiste omandamisele, vaid lisab motivatsiooni, sest tekib omanikutunne ja suureneb tõhusus (Fortus \& Krajcik, 2015).

Probleeme lahendades loovad õpilased mitu versiooni esemetest või toodetest, mille eesmärk on anda vastus mõnele küsimusele või lahendada mõni probleem. Disainiprotsessi osana analüüsivad ja tõlgendavad õpilased andmeid, mis toetavad nende disainilahendusi. Disainipõhistes teadusuuringutes osalemine erineb muudest teaduse õpetamise viisidest selle poolest, et õpilased hakkavad tajuma teaduse õppimist kui millegi tegemist, mis on seotud lahenduste leidmisega nende jaoks olulistele küsimustele ja probleemidele. Selle tulemusena nihkub vastutus õppimise eest õpilasele. Õpilaste ehitatud tehisesemed on oluline hindamisvahend, sest need annavad ülevaate õpilaste üha suurenevatest teadmistest.

Kuna tehisesemed ja tooted näitavad, mida õpilased on õppinud, siis on nende põhjal võimalik hinnata, kui palju nad teadust mõistavad (Krajcik \& 
Shin, 2014). Disainipõhise uurimuse tulemusel valmistavad õpilased tehisesemeid, mis nõuavad tegelemist disainiprobleemidega ja mis näitavad, mida nad on õppinud. Õpetajad soovitavad õpilastel sageli tutvustada oma töid klassikaaslastele, õpetajatele, vanematele ja laiemale kogukonnale. Me viitame toodetele kui tehisesemetele, sest nagu ajaloolisedki esemed, on need nii objektid kui ka tõendusmaterjal selle kohta, et õpilased on tegelenud teadusega. Kui õpilased valmistavad toote, siis ei omanda nad üksnes uusi teadmisi, vaid neis kujuneb ka omanikutunne selle toote vastu ja teadmine, et nad oskavad oma teadmisi kasutades midagi valmistada.

Tehisesemete valmistamine ja nende tutvustamine teistele teenivad mitut eesmärki. Esiteks on need käegakatsutavad ja motiveerivad. Tehiseseme tutvustamine klassikaaslastele, professionaalidele ja kogukonna liikmetele annab õpilaste tegevusele väljundi ja võimaluse teistele oma tööst rääkida. Teiseks aitavad tehisesemed õpilastel oma teadmisi laiendada ja neid teistele esitleda. Kuna tehisesemed (nt mudelid, ettekanded, videod, uued tooted ja arvutiprogrammid) on konkreetsed ja selgesõnalised, on neid võimalik teistega jagada ja ka kritiseerida. Selline tagasiside annab õpilastele võimaluse järele mõelda, süvendada teadmisi ja oma töö uuesti üle vaadata. Kolmandaks saavad õpilased tehisesemete kaudu näidata, mida nad on kogu disainiprotsessi vältel õppinud, ning dokumenteerida kogu õppeprotsessi mõnikord terve õppeaasta vältel. Kuna tehisesemed kajastavad õppetegevust pikema ajavahemiku vältel, siis on nende põhjal võimalik kindlaks teha, kuidas õpilaste teadmised ja arusaamad ajapikku arenevad.

\section{Uus lähenemine disainile: tehnoloogiline disain}

Tehnoloogiliste vahendite abil on võimalik STEM-ainetes luua õpikeskkond, milles õpilased aktiivselt teadmisi omandavad (National Research Council, 2011b; Novak \& Krajcik, 2005; Songer, 2007). Tehnoloogilisi abivahendeid tuleks kasutada õpilaste toetamiseks disainipõhise hariduse omandamisel. Tehnoloogiliste abivahendite kaasamine STEM-haridusse muudab õpikeskkonna autentsemaks ja õpilastele omasemaks. Õpilased võivad kasutada tehnoloogiat eesmärgiga saada ligipääs reaalsetele andmetele veebis, laiendada mõttevahetust ja teha teistega võrgustike kaudu koostööd, valmistada arvutiprogrammide prototüüpe, luua mänge, mida saaks teistega mängida, töötada välja mudeleid, et lahendusi katsetada, kasutada andmete analüüsimiseks graafikuid ja visualiseerimisvahendeid, valmistada omaloomingulisi multimeediatöid ning luua seadmete tööks vajalikke programme. Need on tegevused, mida nad näevad ja teavad professionaale tegevat. Lisaks muudavad tehnoloogia pakutavad multimodaalsed 
võimalused ja multimeedia info hõlpsamini kättesaadavaks mitte ainult füüsiliselt (võimaldades lihtsat juurdepääsu infole), vaid ka intellektuaalselt (aidates õpilastel uut teavet olemasolevate arusaamadega siduda).

Oma disaini loomiseks peavad õpilased kõigepealt mudelid välja töötama. Mudelite ehitamise ${ }^{2}$ projektist saavad õpilased ja õpetajad praktilist kasu. Nimelt uuris selle projekti raames Michigani Osariigi Ülikool (Michigan State University) koos Concordi konsortsiumiga (Concord Consortium), kuidas saaksid õpilased ehitada dünaamilisi mudeleid, hinnates pidevalt oma töö tulemusi. STEM-ainetes on hädavajalik, et õpilased looksid ja katsetaksid eri mudeleid. Tehnoloogia abil on võimalik õpetajatel sellele taskukohasemaid lahendusi leida. Meie lisame sellesse nimekirja kaks tasuta abivahendit.

LEGO on olnud populaarne komponent STEM-tegevustes ning seda saab tasuta kasutada. Google Chrome ja LEGO on loonud veebisaidi (https://www.buildwithchrome.com), kus õpilased saavad välja töötada oma disaini. Kuna tegemist on tasuta tööriistaga, siis saavad ópilased sellel veebisaidil teha vaid piiratud hulgal tegevusi, kuid siiski on selle abil võimalik ehitada mitmesuguseid struktuure. See on suurepärane abivahend kasutajatele, kelle teadmised STEM-valdkonnas on veel piiratud. Veebisaidil loodud disainilahendused saab ühendada õpilase asukohaga, nii et õpilastel kõikjal maailmas on võimalik võrrelda oma mudeleid teiste loominguga.

Neile, kes on STEM-valdkonnas juba edasi jõudnud, võiksid õpetajad soovitada veel ühte veebisaiti: http://www.algodoo.com/. Algodoo toetab kahedimensiooniliste interaktiivsete mudelite loomist. Kasutades Algodood, saavad õpilased luua autode, sisepõlemismootorite, tammide ja inimese anatoomia mudeleid. Hoolimata sellest, et Algodoo keskendub peamiselt füüsikale, on see siiski väga võimas tööriist loodusteaduste õpetamiseks. Seda kasutades saavad õpilased tundma õppida mitmeid suuri ideid, sealhulgas jõudu, valgust ja energia ülekandmist.

\section{STEM-õppeks sobiva keskkonna hindamise kriteeriumid}

Viimastel aastatel on Ameerika meediakompanii U.S. News \& World Report hakanud keskkoole hindama uute kriteeriumite alusel. Üks parimatest STEM-valdkonna koolidest on asetanud insenerit eaduse aukohale ning keskendunud õpilaste kaasamisele tootmisse, milles on ühendatud arhitektuur ja arvutipõhised tegevused. Teine viie parima hulka kuuluv kool keskendub õpilaste uuenduslikkuse arendamisele, kombineerides

Selle projektiga saab tutvuda veebisaidil https://concord.org/projects/building-models. 
matemaatikat, loodusteadusi ja tehnoloogiat. Kõikidele neile koolidele on omane õpilaste loovuse toetamine. Sellises keskkonnas on saanud populaarseks robootikavõistlus. Praegu toetab NASA (Riiklik Aeronautika ja Kosmoseagentuur) enam kui kahtekümmet robootikavõistlust, mis hõlmavad kõike alates veealustest robotitest kuni kütuseelementide süsteemideni.

Tabel 4. STEM-õpikeskkonna hindamise kriteeriumid

\begin{tabular}{c|l}
\hline 1. & Eri tüüpi STEM-koolide ja neis õppivate õpilaste arv igas piirkonnas \\
\hline 2. & Aeg, mis kulutatakse loodusteaduste õpetamisele algkooliklassides \\
\hline 3. & Loodusteaduste õppimise võimalused algkooliastmes \\
\hline 4. & $\begin{array}{l}\text { Matemaatika ühtseid riiklikke põhistandardeid ning põhi-ja keskkooli loodus- } \\
\text { teadusliku hariduse raamistikku järgivate õppematerjalide rakendamine põhi- ja } \\
\text { keskkooliastmes }\end{array}$ \\
\hline 5. & $\begin{array}{l}\text { Ühtsetes riiklikes põhistandardites ning põhi-ja keskkooli loodusteadusliku } \\
\text { hariduse raamistikus soovitatud sisu ja praktika järgimine tundides }\end{array}$ \\
\hline 6. & Õpetajate ainetundmine loodusteadustes ja matemaatikas \\
\hline 7. & Õpetajate osalemine STEM-valdkonna täiendusõppes \\
\hline 8. & $\begin{array}{l}\text { Õppetegevuste juhtide osalemine täiendusõppes, mis on suunatud STEM-haridust } \\
\text { toetavate õpitingimuste loomisele }\end{array}$ \\
\hline 9. & Loodusteaduste lisamine riiklikesse ja osariikide aruandlussüsteemidesse \\
\hline 10. & $\begin{array}{l}\text { Loodusteaduste lisamine peamistesse riiklikesse põhi- ja keskkooliastme haridus- } \\
\text { algatustesse }\end{array}$ \\
\hline 11. & Riigi ja piirkondliku personali pühendumus loodusteaduste õpetamisele \\
\hline 12. & $\begin{array}{l}\text { Osariigisisesed hindamised, millega mõõdetakse loodusteaduslike ainete õpetamise } \\
\text { peamisi teooriaid ja praktikaid }\end{array}$ \\
\hline 13. & $\begin{array}{l}\text { Riiklikud ja osariikide kulutused, mis tehakse põhi- ja keskkooliastmes } \\
\text { STEM-valdkonna õpetajaskonna tugevdamiseks }\end{array}$ \\
\hline 14. & $\begin{array}{l}\text { Riiklik rahastus uuringutele, mis on kindlaks määratud dokumendiga „Edukas } \\
\text { STEM-haridus põhi-ja keskkooliastmes" }\end{array}$ \\
\hline &
\end{tabular}

USA Riiklik Teadusnõukogu (National Research Council, 2013) on kehtestanud 14 kriteeriumit, mille järgi hinnata STEM-haridust põhi- ja keskkooliastmes. Need kriteeriumid on loetletud tabelis 4. Kriteeriumite väljavalimisega tegelenud komitee määras kindlaks kuus kõige olulisemat, mis on tabelis esile toodud paksu ja kaldkirjaga. Pange tähele, et loodusteaduste õpetamisele kulutatud aega algkooliastmes loetakse põhikriteeriumiks, mille alusel määratakse kindlaks STEM-haridusega seotud 
edukad piirkonnad. See kriteerium on tihedalt seotud ideega, et mõistmine kujuneb välja ajapikku. Algkooliklassides ei ópetata loodusteadusi, kuid selleks, et parandada ópilaste suutlikkust omandada STEM-aineid, on algklassides vaja ilmtingimata nendega kokku puutuda. Õpetajatele aga tekitab selleks vajalike teadmiste omandamine stressi. Et STEM-haridus oleks edukas, vajame tõhusat õpetajate ettevalmistust ja professionaalseid õppeprogramme. Õpetajatel on tarvis põhjalikke teadmisi loodus- ja täppisteadustest ning ühtlasi peavad nad mõistma, mida tähendab loodusja inseneriteadusega tegelemine. Kõikide kooliastmete õpetajad peavad samamoodi nagu õpilased osalema loodus- ja inseneriteaduse praktilises rakendamises.

Rõhutamist väärib, et STEM-hariduse rahastamine on üks olulistest kriteeriumitest selles nimekirjas. STEM-haridus saab olla edukas vaid siis, kui seda rahastab valitsus. STEM-keskkond vajab ruumi ja vahendeid.

\section{STEM-hariduse rakendamisega seotud probleemid}

STEM-hariduse ja disaini kasutamine klassiruumis on õpetajate jaoks keeruline. Allpool teeme kokkuvõtte peamistest probleemidest, millega õpetajad, koolijuhid ja koolisüsteemid peavad STEM-hariduse andmisel kokku puutuma (Krajcik \& Delen, 2017; Sadler, Coyle, \& Schwartz, 2000).

1. Määratlege selgelt ja täpselt õppe-eesmärgid, mis annavad õpilastele võimaluse oma teadmisi kasutada probleemide lahendamiseks ja nähtuste mõistmiseks. Õppe-eesmärkidele keskendumata kaasatakse õpilased küll tegevustesse, mis võivad olla üsna põnevad, kuid see ei vii neid tõeliste probleemide lahendamise ega uute ideede õppimiseni tulevikus.

2. Selgitage õpilastele püstitatud disainiülesandeid selgelt ja lühidalt. Disainiülesannete selgus aitab õpilastel nii disainiga seotud eesmärke kui ka õppe-eesmärke saavutada. Õpilastele peab jääma võimalus disainiülesandeid viimistleda ja parandada. Sellise õpikeskkonna loomiseks, mis motiveeriks õpilasi mitte loobuma keerulise probleemi lahendamisest, tuleb nad protsessi täielikult kaasata. Õpilaste omanikutunnet ja panustamistahet saab suurendada probleemi täpsustamise abil.

3. Mõelge õpilaste jaoks välja motiveerivad ja põnevad disainiülesanded. Me peame olema teadlikud taustast, mis on õpilastel klassiruumi sisenemisel. Mõned õpilased on disainiülesannete puhul palju motiveeritumad kui teised. Me peame aitama õpilastel mõista, miks on probleemi lahendamine oluline.

4. Töötage välja prototüübid, mida õpilased saaksid paremaks muuta, et aidata neil disainiprotsessi käigus konstrueerimisoskusi arendada ja 
enesekindlust koguda. Kui õpilased ehitavad oma seadmete uusi versioone, siis muutuvad nad üha enesekindlamaks ja nende tegutsemine üha vilunumaks. Tavaliselt ei ole ühegi vanuseastme loodusteaduste ja matemaatikaõpetajad harjunud sellega, et õpilased ehitavad klassis oma teadmiste näitamiseks mingeid tooteid. Kui soovite õpilasi disainiprotsessi kaasata, siis peate neile andma aega õppida erinevate tööriistade kasutamist.

5. Laske õpilastel oma mudelitest mitu versiooni teha, nii et nad saaksid enda valmistatud seadmeid muuta ja katsetada. Nagu disainiprotsessi tutvustuses (joonis 1) märgitud, on selle protsessi ülioluline osa teistelt inimestelt ja katsetamise teel saadud tagasiside ning seejärel selle tagasiside kasutamine toote ümbertegemiseks. Ei õpilased ega ka õpetajad ole harjunud toodet mitu korda uuesti tegema, kuid just korduste kaudu muudavad disainerid toote paremaks, lahendavad probleeme ja saavad ise targemaks.

6. Pakkuge õpilastele abivahendeid, mis toetaksid disainiprotseduuriga tutvumist. Disainimine on keeruline protsess, mille jooksul tuleb õpilasi igati toetada. Näiteks vajavad ópilased tuge mudelite prototüüpide valmistamisel, et oma lahendusi katsetada.

7. Pakkuge õpilastele võimalust valmistada mitu versiooni. Mitme versiooni valmistamine tähendab ka seda, et õpetajatena peame lubama läbikukkumist disainimisel. Probleemidele on keeruline lahendusi leida ja alguses ei saa õpilased sellega hakkama, kuna nende pakutud disain ei pruugi nõudmistele vastata.

8. Õpilaste disainikatsetused saab muuta edukamaks, kui ühendada disainiprotsess teadusega, millel need põhinevad. Kui tahame, et õpilased õpiksid disainiprotsessis osalemise kaudu, siis tuleb neile selgitada teaduslikke ideid, millele nende disain toetub. Inseneridel on loodusteadustest väga põhjalikud teadmised. Kas te annaksite miljon dollarit maksva silla ehitamise inimese kätesse, kes ei teaks midagi jõu toimimisest ega materjalidest?

9. Koostage vaatlusprotokolle, mille abil saab kujundavalt hinnata õpilaste tegevust disainiprotsessi käigus. Kujundav hindamine on õpilaste disaini-, koostöö- ja suhtlemisoskuse parandamiseks väga tähtis. Õpilased peavad tehisesemeid tutvustama mitmesugustele kuulajaskondadele ja saama tagasisidet oma töö kohta. Õpilastel on sellest kasu kolmel viisil: 1) nad näevad, et see, mida nad koolis teevad, on teiste jaoks oluline ja väärtuslik, 2) nad saavad oma töö kohta tagasisidet ja 3) nad tutvustavad teistele oma probleemilahendusi. 
10. Tagage, et õpilastel oleks võimalik oma disainitud esemeid tutvustada ja nende kohta tagasisidet saada. Tutvustamine ja tagasiside kogumine võtavad aega, kuid see on disainiprotsessi ülioluline osa.

\section{Näited STEM-hariduse ja disainiprotsessi kohta}

Siiani oleme kokkuvõtlikult käsitlenud kahte suurt ideed: 1) STEM-valdkond mõjutab meie elu igal sammul ja 2) oluline on luua STEM-keskkond, mis toetaks suurte ideede järkjärgulist põhjalikku omandamist, kaasata õpilased disainiprotsessi, pannes rõhku loodus- ja inseneriteaduste praktilisele poolele, ning luua keskkond, mis motiveeriks õpilasi ja paneks neid pingutama. Allpool tutvustame kahte STEM-haridusega seotud näidet, millest selgub, kuidas õpilased ja entusiastlik õpetaja saavad disaini ning STEM-hariduse valdkonna ideid rakendada.

Entusiastlik loodusainete õpetaja Burhan Zenginsan on võtnud jõu, energiaülekande ja aerodünaamilisuse õpetamisel appi kartongi, silikooni, tühjad pudelid ja plasttorud (vt joonis 2). Ta annab õpilastele kartongi ja palub neil valmistada paberraketid (õpilaste kaasamine disainiprotsessi, rõhutades loodus- ja inseneriteaduslikke tavasid). Iga õpilane valmistab oma mudeli, lõigates selle kartongist välja ja kleepides silikooni abil kokku. Seejärel asetab õpetaja raketi plasttoru tippu, mille teises otsas on tühi veepudel. Siis hüppavad õpilased tühjale veepudelile ja jälgivad, milline rakett lendab kõige kõrgemale (kontekst, mis motiveerib õpilasi ja sunnib neid pingutama). Niimoodi saab plasttorust valmistatud lihtsa mehhanismi külge kinnitatud paberraketiga näidata, kuidas õpilase hüpe põhjustab energia ülekande. Õpilaste rakendatud jõust sõltub, kui kõrgele saab rakett lennata. Kõigepealt katsetavad õpilased, kui palju mõjutab erineva jõu rakendamine raketi lennukõrgust. Seejärel võrreldakse, kuidas erinev disain (nt palutakse igal õpilasel disainida raketile erinev tiivakuju) võib mõjutada paberlennuki lennukõrgust (suurte ideede järkjärguline põhjalik omandamine). Õpilased peavad näitama, kuidas nad eksperimendist aru said, selgitades, miks rakett lendab just nii, nagu ta seda teeb.

Teine näide puudutab roboteid. Me teame, et robotid muudavad meie elu lihtsamaks, kuid kes oleks võinud arvata, et nad võivad päästa kutsika elu? Istanbulis kukkus üks väike koer auku, mis viis $70 \mathrm{~m}$ sügavuse kaevuni. Kui inimesed kuulsid kahtlaseid hääli, helistasid nad lähimasse tuletõrjedepoosse. Kuna koer oli hirmul ja keeldus 10 päeva järjest igasugusest koostööst tuletõrjujatega, oli ainsaks väljapääsuks tema toitmine ja soojuskaamerate abil jälgimine. Kümnendal päeval tulid appi STEM- 
valdkonna teadmised, kui keskkooliõpilased meisterdasid robotkäe, mis haaras koera ümbert kinni ja tõmbas looma maapinnale (Hurriyet Daily News, 2017).

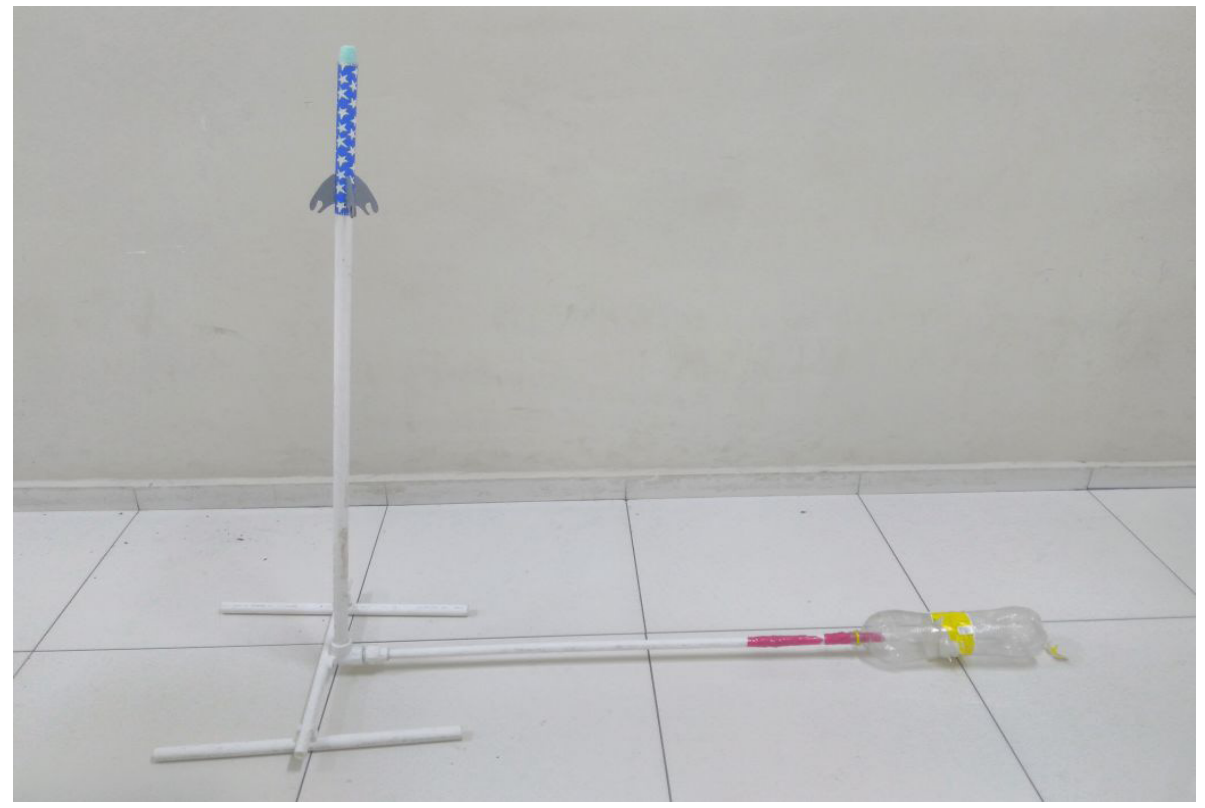

Joonis 2. Paberraketi mudel

\section{Kokkuvõte}

Disainile keskenduva STEM-hariduse kaudu on võimalik toetada õpilasi suurte loodus- ja inseneriteaduslike ideede ja oluliste praktiliste teadmiste omandamisel. Disainikeskkond mõjub ka õpilasi motiveerivalt, sest neil tekib omanikutunne, nad peavad oma ideid tutvustama ja tulemuslikult tegutsema. Enamgi veel, disainiprotsessi kaasatud õpilased saavad arendada selliseid 21. sajandil vajalikke oskusi nagu probleemilahendus- ja suhtlemisoskus ning koostöövõime.

Põhi- ja keskkooli tundides tuleb toetada õpilaste STEM- ja disainipõhist õpet, et aidata neil saavutada olulisi õpitulemusi, mis on hädavajalikud maailmas, kus nad elavad. STEM-hariduse toomine põhi- ja keskkooli nõuab muudatusi senises õppetegevuses ja uut mõtteviisi, kuid nende raskuste ületamise tulemusena on võimalik tagada, et põhi- ja keskkooliõpilased on varustatud praktiliste teadmistega, mis aitavad neil elus hakkama saada ja maailma paremaks muuta. Sellised kogemused võimaldavad tänastel õpilastel leiutada homseid lahendusi, võib-olla isegi 
leida lahendusi taastuva ja puhta energia allikatele, millest võib olla kasu kõikidele riikidele maailmas. Meie eesmärk STEM-haridusega seoses peaks olema ópilaste varustamine teadmiste ja oskustega, mille abil lahendada keerulisi probleeme. Teadmised ja tunne „Mina suudan!“ on üliolulised kõikidele õpilastele, et neist kasvaks täisväärtuslikud 21. sajandi kodanikud. Kõik põhi- ja keskkooliõpilased maailmas peaksid saama kogeda avastamisrõõmu ja innovatsiooni, lahendades probleeme ja valmistades järgmistele põlvkondadele kasulikke tooteid.

\section{Kasutatud kirjandus}

American Association for the Advancement of Science (1989). Science for all Americans. Washington. Retrieved from http://www.project2061.org/publications/sfaa/online/sfaatoc.htm.

Carey, B. (2016, April). Chip, implanted in brain, helps paralyzed man regain control of hand. The New York Times. Retrieved from http://www.nytimes.com/2016/04/14/ health/paralysis-limb-reanimation-brain-chip.html?_r=0.

Corcoran, T. B., Mosher, F. A., \& Rogat, A. (2009). Learning progressions in science: An evidence-based approach to reform (CPRE Report). New York: Columbia University.

Damelin, D., Krajcik, J., McIntyre, C., \& Bielik, T. (2017). Students making system models: An accessible approach. Science Scope, 40(5), 78-82. https://doi.org/10.2505/4/ss17_040_05_78

Delen, I., \& Krajcik, J. (2016). Using mobile devices to connect teachers and museum educators. Research in Science Education, 1-24. https://doi.org/10.1007/s11165-015-9512-8

Duncan, R., Krajcik, J., \& Ravit, A. (2016). Disciplinary core ideas: Reshaping teaching and learning. Arlington: National Science Teachers Association Press.

Fortus, D., Dershimer, C. R., Krajcik, J., Marx, R. W, \& Mamlok-Naaman, R. (2004). Design-based science and student learning. Journal of Research in Science Teaching, 41(10), 1081-1110. https://doi.org/10.1002/tea.20040

Fortus, D., \& Krajcik, J. (2015). Engineering in IQWST. In C. Sneider (Ed.), The go-to guide for engineering curricula grades 6-8: Choosing and using the best instructional materials for your student. Thousand Oaks: Corwin Press.

Greeno, J. G., \& Engestrom, Y. (2014). Learning in activity. In R. K. Sawyer (Ed.), The Cambridge handbook of the learning sciences (2nd ed., pp. 128-147). New York: Cambridge University Press.

Hurriyet Daily News (2017). Puppy stuck in well rescued after 10 days in Istanbul. Retrieved from http://www.hurriyetdailynews.com/puppy-stuck-in-well-rescuedafter-10-days-in-istanbul.aspx?pageID $=238 \& n I D=109770 \& N e w s C a t I D=378$.

Kesidou, S., \& Roseman, J. E. (2002). How well do middle school science programs measure up? Findings from Project 2061's curriculum review. Journal of Research in Science Teaching, 39(6), 522-549. https://doi.org/10.1002/tea.10035 
Klager, C., Schneider, B., Krajcik, J. S., Lavonen, J., \& Salmela-Aro, K. (2017). Creativity in a project-based physics and chemistry intervention. Paper presented the annual meeting of NARST, April, 2017, San Antonio, Texas.

Krajcik, J. S., \& Czerniak, C. (2013). Teaching science in elementary and middle school classrooms: A project-based approach (4th ed.). London: Routledge.

Krajcik, J., \& Delen, I. (2017). How to support students in developing usable and lasting knowledge of STEM. International Journal of Education in Mathematics, Science and Technology, 5(1), 21-28. https://doi.org/10.18404/ijemst.16863

Krajcik, J. S., \& Shin, N. (2014). Project-based learning. In R. K. Sawyer (Ed.), The Cambridge handbook of the learning sciences (2nd ed., pp. 275-297). New York: Cambridge University Press.

National Research Council (2007). Taking science to school: Learning and teaching science in grades K-8. Washington: The National Academies Press.

National Research Council (2011a). Successful K-12 STEM Education: Identifying Effective Approaches in Science, Technology, Engineering, and Mathematics. Washington: The National Academies Press.

National Research Council (2011b). Learning science through computer games and simulations. Washington: The National Academies Press.

National Research Council (2012). A framework for K-12 science education: Practices, crosscutting concepts, and core ideas. Washington: The National Academies Press.

National Research Council (2013). Monitoring progress toward successful K-12 STEM education: A nation advancing? Washington: The National Academies Press.

National Research Council (2014). STEM integration in K-12 education: Status, prospects, and an agenda for research. Washington: The National Academies Press.

National Science Foundation (2016, December). NSF awards $\$ 61$ million in new projects to enhance understanding of STEM education and workforce development. Retrieved from https://www.nsf.gov/news/news_summ.jsp?cntn_id=190509.

Novak, A., \& Krajcik, J. S. (2005). Using learning technologies to support inquiry in middle school science. In L. B. Flick \& N. G. Lederman (Eds.), Scientific inquiry and nature of science: Implications for teaching, learning, and teacher education. Dordrecht: Kluwer Academic Publishers.

Osborne, J. F., \& Dillon, J. (2008). Science education in Europe: Critical reflections. A Report to the Nuffield Foundation. Retrieved from http://www.nuffieldfoundation.org/sites/default/files/Sci_Ed_in_Europe_Report_Final.pdf.

Roseman, J. E., Stern, L., \& Koppal, M. (2010). A method of analyzing the coherence of high school biology textbooks. Journal of Research in Science Teaching, 47(1), 47-70. https://doi.org/10.1002/tea.20305

Sadler, P. M., Coyle, H. P., \& Schwartz, M. (2000). Engineering competitions in the middle school classroom: Key elements in developing effective design challenges. The Journal of the Learning Sciences, 9(3), 299-327. https://doi.org/10.1207/S15327809JLS0903_3

Sanders, M. (2009). STEM, STEM education, STEM mania. The Technology Teacher, $68(4), 20-26$.

Sawyer, R. K. (Ed.) (2014). The Cambridge handbook of the learning sciences (2nd ed.). New York: Cambridge University Press. 
Schwarz, C., Passmore, C., \& Reiser, B. J. (Eds.) (2016). Helping students make sense of the world using next generation science and engineering practices. Arlington: National Science Teachers Association Press.

Songer, N. B. (2007). Digital resources or cognitive tools: A discussion of learning science with technology. In S. Abell \& N. Lederman (Eds.), Handbook of research on science education (pp. 471-491). Mahwah: Erlbaum.

Stevens, S., Sutherland, L., \& Krajcik, J. S. (2009). The big ideas of nanoscale science and engineering: A guidebook for secondary teachers. Arlington: National Science Teachers Association Press.

U.S. Department of Education Office for Civil Rights (2014). Civil rights data collection. Data snapshot: College and career readiness. Retrieved from https://www2.ed.gov/about/offices/list/ocr/docs/crdc-college-and-career-readiness-snapshot.pdf.

Vedder-Weiss, D., \& Fortus, D. (2012). Adolescents' declining motivation to learn science: A follow-up study. Journal of Research in Science Teaching, 49(9), 10571095. https://doi.org/10.1002/tea.21049 